\title{
Learning styles and teacher efficacy among prospective teachers based on diverse variables
}

\author{
Tazegül Demir Atalay \\ Department of Social Sciences and Turkish Education, Kafkas University, Turkey
}

\begin{tabular}{l}
\hline \hline Article Info \\
\hline Article history: \\
Received Apr 19, 2019 \\
Revised Jun 27, 2019 \\
Accepted Aug 19, 2019 \\
\hline
\end{tabular}

Keywords:

Kolb learning style model

Learning styles

Motivation

Self-efficacy

Teacher efficacy

\begin{abstract}
The main aim of this study was to explore learning styles and teacher efficacy of prospective teachers, evaluate them based on department, gender, high school type and educational level of parents, and identify whether there is any relationship between teacher efficacy and learning styles. This is a descriptive study that was conducted using survey model. The study group consisted of 170 prospective teachers in the Faculty of Education, Kafkas University during the 2018-2019 academic year. Research data were gathered through "Teachers' Sense of Efficacy Scale" and the "Kolb Learning Style Inventory". The study came to the conclusion that prospective teachers mostly had diverging and converging learning styles while assimilating and accommodating learning styles were least preferred, their teacher efficacy was "sufficient", and teacher efficacy scores differed significantly in relation to learning styles. The study also found a significant relationship between some variables, i.e. department, gender, high school type and educational level of parents, and the prospective teachers' learning style and occupational self-efficacy level. The study discussed these findings from various aspects and proposed recommendations.
\end{abstract}

Copyright $@ 2019$ Institute of Advanced Engineering and Science. All rights reserved.

\section{Corresponding Author:}

Tazegül Demir Atalay,

Department of Social Sciences and Turkish Education,

Kafkas University,

36100, Kars, Turkey.

Email: tazeguldemir@gmail.com

\section{INTRODUCTION}

Self-efficacy is a cognitive construct that corresponds to personal judgments for individuals to display their beliefs and capabilities to a certain extent, and affects their choice of activity, effort and performance. Individuals with sufficient self-efficacy are willing to participate in a task, to strive for a long time and work hard; they are also more disposed to fulfil a task when facing challenges compared to those who doubt their own capabilities [1]. Thus, motivating individuals first to do their job helps them have perceived self-efficacy in work environment. Bandura maintains that people's motivation, how they are affected by events, and their acts depend more on what they believe rather than what is real, and identifying the level of self-efficacy in individuals can help to find out what they can do with the capabilities and knowledge they have. Self-efficacy belief determines how individuals feel, think, motivate themselves and behave [2]. Therefore, it is one of the key aspects of motivation. Self-efficacy is also important in terms of identifying people's choices to fulfil a task, the effort they exert when performing this task, and the amount of performance they display [1]. According to Bandura, self-efficacy is crucial for individuals to bring out their capabilities and display new behaviour. People prefer certain behaviour to perform a task and act purposefully, which relate to people's perceived self-efficacy. Here, there are two dimensions of behaviour: expectation for the outcome and expectation of self-efficacy. Self-efficacy belief that plays a highly significant role in the individual's behaviour develops based on four sources. These are a) first-hand 
experience of a similar behaviour (complete and proper experiences), b) to observe similar behaviours by someone else (social models), c) to be convinced by an authority (verbal persuasion) and d) perception of one's own physiological and emotional states (physiological and emotional states) [2].

The most effective of them is personal experiences. Self-efficacy belief affects the goals people set for themselves, how much effort they will put in to achieve these goals, how much they can endure the challenges they face to reach their goals, and their response to failure [3]. Self-efficacy can be described as the person's feeling capable at doing something and the belief that they can do it. Having self-efficacy for one's occupation in particular contributes to having high occupational achievement. It may be noted that occupational self-efficacy is highly important for an occupation like teaching that is based on establishing relations with people. Occupational self-efficacy is also about knowing the particulars of one's own learning. The awareness of teachers or prospective teachers about their own learning also helps them to predict and tolerate students' differences in this regard. In this regard, the significance of identifying the learning styles comes into play.

Learning style is preferred individual methods to grasp and process knowledge $[4,5]$. Learning style can be defined as personal characteristics and preferences that show learning people's way of perceiving education and teaching environment, how they interact with this environment and how they respond to information. Research on learning styles started in the 1940s and created an extensive area of use in the 1970s. Since the 1940s, many models have been proposed by the researchers to explore learning styles. They include Gregorc learning style model, Dunn learning style model, McCarthy's 4MAT and Kolb learning style model.

Kolb's experience based learning model is built on the learning cycle model proposed by Jung in 1923. Influenced by Jung's model, Kolb studied experience based learning since the 1960s, and developed the experience based learning model that focused on people's learning styles in the 1970s. He described learning as a process comprising four stages, and indicated that individuals have some concrete experiences as a natural result of the environment they live in, and they observe and reflect these experiences in different ways. In addition, he stressed that reflective observation is influential in abstract conceptualisations and developing principles and generalisations. Ultimately, individuals use such generalisations in their future activities and later learning as a guide [4, 6]. Thus, learning achieved in four steps continues for life, a new experience is gained every time and these experiences form the basis for next learning. Kolb suggests that learning occurs by transforming information to experience, and mentions about four main categories in his learning style model: concrete experience, abstract conceptualisation, active experimentation and reflective observation. According to the experience based learning theory, learning is a cycle. For individuals, one of these four main categories takes primacy at times and it is inevitable to pass through this cycle numerous times in a learning experience [7]. According to Kolb, there are two dimensions in the learning process. The first is from abstract conceptualisation to concrete experience and the second is from active experimentation to reflective observation. The first dimension describes how individuals take in information while the second dimension explains how they process it. According to the Kolb learning style model, individuals perceive information by experiencing or thinking, and process it by observing or acting. The way of learning that represents each learning style is unique. For example, learning occurs by 'sensing' for concrete experience, by 'observing and listening' for reflective observation, by 'thinking' for abstract conceptualisation and by 'acting' for active experimentation. The learning style of every individual is a combination of the four main learning modes. These are 'diverging' learning style which combines concrete experience and reflective observation, 'assimilating' learning style as the combination of reflective observation and abstract conceptualization, 'converging' learning style as a mixture of abstract conceptualization and active experimentation, and 'accommodating' learning style blending concrete experience and active experimentation [4, 6-8]. Learning style and occupational self-efficacy may be considered as two constructs affected by each other. This assumption is also the source of the present study. Accordingly, the main aim of this study was to examine learning styles and teacher efficacy of prospective teachers, evaluate them in relation to department, gender, high school type and educational level of parents, and identify whether teacher self-efficacy is related to learning styles.

\section{RESEARCH METHOD}

\subsection{Research pattern and study group}

This is a descriptive study that was conducted by using survey model. The study group consisted of 170 prospective teachers in $4^{\text {th }}$ grade in Mathematics, Science, Social Sciences and Turkish Education departments in the Faculty of Education at Kafkas University during the 2018-2019 academic year. The study employed senior students in the study group, because most of the courses on professional teaching knowledge that have an impact on students' teacher efficacy have usually been taken until final year. As for

The examination of learning styles and teacher efficacy in prospective teachers... (Tazegül Demir Atalay) 
the reason for selecting students from the said departments, the possibility that variables such as professor profile in these departments, the courses offered, learners' sources of information, etc. may cause differences in students' learning styles [9]. In the study, 94 participants were female (55\%); 50 (29.4\%) were in Science Education, 38 (22.3\%) Mathematics Education, 33 (19.4\%) in Social Sciences Education, and $49(28.8 \%)$ in Turkish Education departments. 80 participants (47\%) graduated from Anatolian High School while the mothers of $80(47 \%)$ and fathers of $59(35 \%)$ were primary school graduate.

\subsection{Data collection tools}

The data on the prospective teachers' personal information were gathered by using the "Personal Information Form" prepared by the researchers while data on occupational self-efficacy and learning styles were collected by using "Teachers' Sense of Efficacy Scale" developed by [10] and adjusted to Turkish by [11], and the "Kolb Learning Style Inventory" developed by [5] and adjusted to Turkish by [12], respectively . The Teachers' Sense of Efficacy Scale was designed as a 9-point Likert type measurement instrument, and subjected to both confirmatory factor analysis and reliability test. The result of confirmatory factor analysis demonstrated that the scale consisted of 3 factors -compatible with the factor structure of the original scaleand each subscale comprised 8 items. To test the reliability of the scale, alpha coefficients were calculated and it was found that the Cronbach's alpha reliability coefficient was .93 for the whole scale, and $.82, .86$ and .84 for the subscales [11]. The Kolb Learning Style Inventory consists of 12 completion type items, and four choices in every item are scored between 1 and 4 . The minimum score on the scale is 12 while maximum score is 48 .

After this scoring, combined score is calculated, and expressed as Abstract Conceptualization (AC) Concrete Experience (CE), and Active Experimentation (AE) - Reflective Observation (RO). The scores vary between -36 and +36 . Combined scores are inserted on the coordinate system developed by Kolb, and thus, learning style of the individual is determined. The scale adjusted to Turkish has four learning styles (Diverging-Assimilating-Converging-Accommodating) and the alpha reliability coefficients of the combined scores (AC-CE and AE-RO) vary between .58 and .77. The present study recalculated the Cronbach's alpha reliability coefficients of both inventories, and found that the alpha coefficient for the Teachers' Sense of Efficacy Scale overall was .94 while the alpha coefficient for learning styles and combined scores of the Kolb Learning Style Inventory varied between .67 and .86 .

\subsection{Data analysis}

The study used SPSS 15 software to analyze the data collected. The scores of the participating prospective teachers on the Kolb Learning Style Inventory were considered as categorical data, and the scores on the Teachers' Sense of Efficacy Scale as continuous data. Frequency and percentage analyses were performed to examine learning styles of the participants while mean and standard deviation values were taken to determine teacher efficacy. The study performed the chi-square test to identify the difference between the participants' learning styles based on department, gender, high school type and educational level of parents, and the Mann-Whitney $U$ and Kruskal Wallis tests to determine the significant difference between these independent variables and teacher efficacy. Kruskal Wallis test was also used to find out the relationship between the level of teacher efficacy and learning styles of the participants. The descriptive analysis on the Teachers' Sense of Efficacy Scale investigated whether the mean scores were close to 9, and the scoring in Table 1 was taken into account in the assessment [13].

\begin{tabular}{ccc} 
Table 1. Scoring on the teachers' sense of efficacy scale \\
\hline Choice & \multicolumn{3}{c}{ Scoring } \\
\hline Insufficient & $(1)$ & $1.00-1.89$ \\
& $(2)$ & $1.90-2.78$ \\
Moderately sufficient & $(3)$ & $2.79-3.67$ \\
& $(4)$ & $3.68-4.56$ \\
Sufficient & $(5)$ & $4.57-5.45$ \\
& $(6)$ & $5.46-6.34$ \\
& $(7)$ & $6.35-7.23$ \\
& $(8)$ & $7.24-8.12$ \\
& $(9)$ & $8.13-9.00$ \\
\hline
\end{tabular}

\section{RESULTS AND DISCUSSION}

In this part of the study, the data gathered in line with the sub-problems of the study were analysed and presented in tables. According to Table 2, the dominant learning style of the prospective teachers was "diverging" ( $\mathrm{f}=62 ; \% 36.5)$. It was found that $25.3 \%(\mathrm{f}=43)$ of the students had "converging" learning style 
that learns through thinking-acting, 20.6\% ( $\mathrm{f}=35$ ) had "accommodating" learning style that learns through acting and feeling, and $17.6 \%$ ( $\mathrm{f}=30)$ had "assimilating" learning style that learns through thinking and observing. This finding suggests that the participants mostly had diverging and converging learning styles while accommodating and assimilating learning styles were least preferred.

Table 2. Distribution of learning styles among the prospective teachers

\begin{tabular}{ccccc}
\hline \multicolumn{5}{c}{ Learning styles } \\
Accommodating & Diverging & Converging & Assimilating \\
\hline $\mathrm{f}$ & 35 & 62 & 43 & 30 \\
$\%$ & 20.6 & 36.5 & 25.3 & 17.6 \\
\hline
\end{tabular}

The analysis of Table 3 indicates that there was a significant difference between the prospective teachers' learning styles based on department $\left(X^{2}=19.03, p<.05\right)$. The dominant learning style of the participants in Turkish Education Department (34.7\%) was "diverging" $(\mathrm{n}=17)$ while the dominant learning style of those in Social Sciences Department was "converging" ( $\mathrm{n}=12,36.4 \%)$ and "accommodating" ( $\mathrm{n}=11$, $33.3 \%$ ). Most of the students in Science and Mathematics Education departments predominantly had "diverging" learning style $\left(\mathrm{n}_{\text {science }}=19,38 \% ; \mathrm{n}_{\text {math }}=18,47.4 \%\right)$. Cramer's $\mathrm{V}$ used to measure the effect size of the department variable on learning style was found to be .19. This result indicates that department had a moderate effect on the participants' learning styles [14].

Table 3 shows that there was no significant difference between the participants' learning styles in relation to gender $\left(\mathrm{X}^{2}=2.31, \mathrm{p}=.51\right)$. It was found the dominant learning style among the majority of female and male participants $\left(\mathrm{n}_{\text {female }}=34,36.2 \% ; \mathrm{n}_{\text {male }}=28,36.8 \%\right)$ was "diverging".

Table 3. Distribution of learning styles based on independent variables

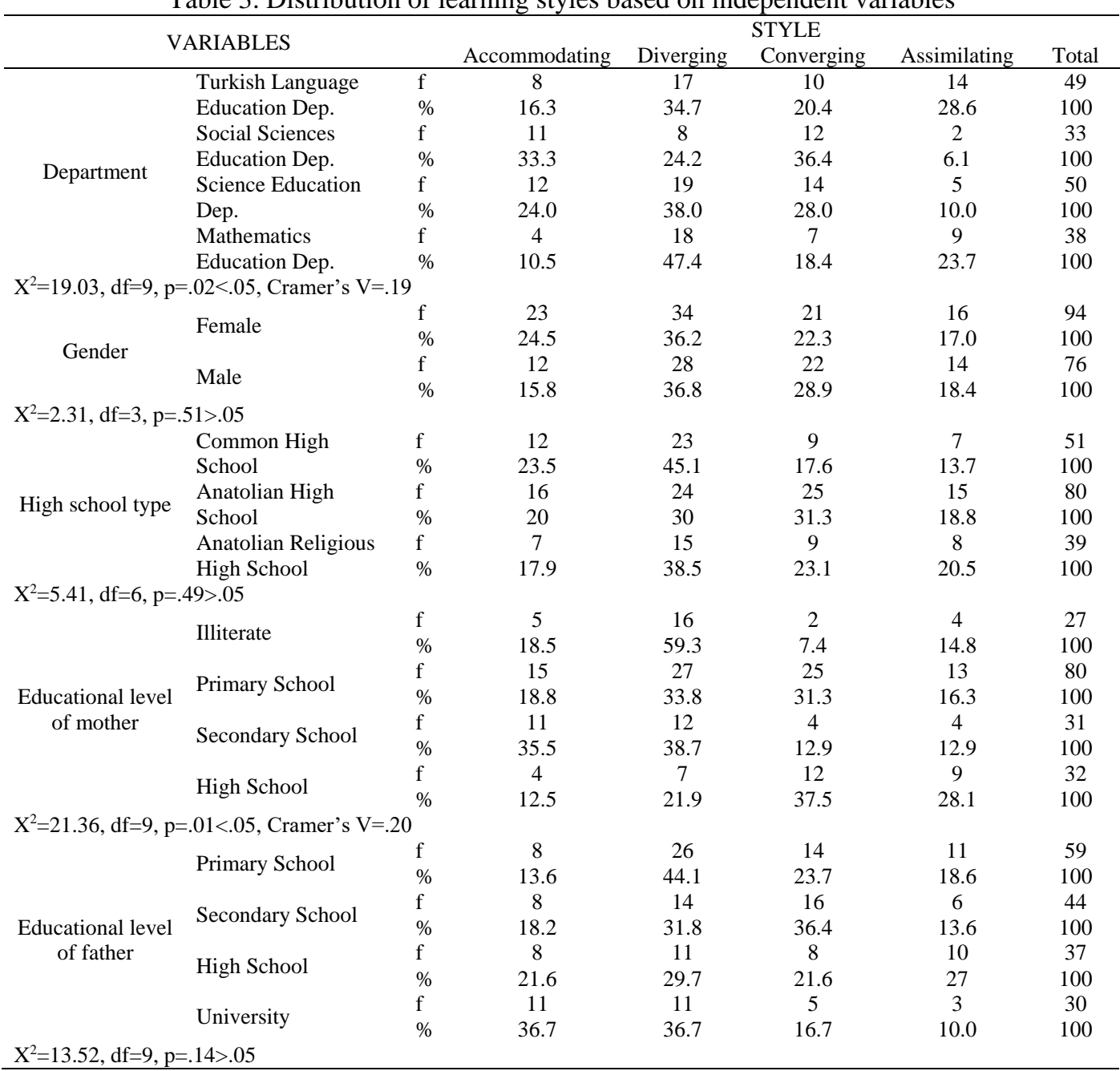

The examination of learning styles and teacher efficacy in prospective teachers... (Tazegül Demir Atalay) 
Table 3 shows that 23 female participants had "accommodating" and 21 "converging" and 16 "assimilating" learning style, whereas 22 male participants had "converging", 14 "assimilating" and 12 "accommodating" learning style. It was found that the prospective teachers' learning styles did not differ significantly based on the type of high school they graduated from $\left(X^{2}=5.41, p=.49\right)$. About $45 \%(n=23)$ of Common High School graduates and 38.5\% $(\mathrm{n}=15)$ of Anatolian Religious High School graduates had "diverging" learning style while 31\% $(n=25)$ and $30 \%(n=24)$ of the Anatolian High School graduates had "converging" and "diverging" learning styles, respectively.

The Table 3 points out a significant difference between the participants' learning styles in relation to educational level of mother $\left(X^{2}=21.36, p=.01\right)$. The dominant learning style of $59 \%(n=16)$ of the participants with illiterate mothers, $34 \%(\mathrm{n}=27)$ of the participants whose mothers graduated from primary school, and $39 \%(n=12)$ of those with mothers graduating from secondary school was "diverging", whereas $37.5 \%$ $(\mathrm{n}=12)$ of the participants whose mothers graduated from high school had "converging" learning style. Cramer's V was used to measure the impact of educational level of mother on the participants' learning style, and the effect size was found to be moderate. On the other hand, the analysis of Table 3 indicates that the prospective teachers' learning styles did not differ significantly in relation to educational level of father $\left(\mathrm{X}^{2}=13.52, \mathrm{p}=.14\right) .44 \%(\mathrm{n}=26)$ of the participants whose fathers were primary school graduate and $30 \%$ $(n=11)$ of those with fathers graduating from high school predominantly had "diverging" learning style, and most of the participants whose fathers graduated from secondary school $(36.4 \%, \mathrm{n}=16)$ had "converging" learning style. According to the table, the dominant learning style for the majority of participants with fathers graduating from university was "accommodating" $(37 \%, n=11)$ and "diverging" $(37 \%, n=11)$.

The Table 4 demonstrates mean and standard deviation values for the participants' scores on the Teachers' Sense of Efficacy Scale. According to these values, it was found that the occupational self-efficacy level of the participants was "sufficient" for all the scale factors. According to the table, the factor for which the participants had highest self-efficacy was "efficacy in instructional strategies".

Table 4. Results of descriptive analysis on the teachers' sense of efficacy scale scores

\begin{tabular}{cccc} 
Scale factors & $\mathrm{n}$ & $\bar{X}$ & S.S. \\
\hline Efficacy in student engagement & 170 & 6.51 & 10.24 \\
Efficacy in instructional strategies & 170 & 6.66 & 9.64 \\
Efficacy in classroom management & 170 & 6.63 & 9.84 \\
Total & 170 & 6.60 & 27.23 \\
\hline
\end{tabular}

The analysis of Table 5 shows that the participants' scores on the Teachers' Sense of Efficacy Scale differed significantly in relation to the department variable $(\mathrm{X} 2=8.95, \mathrm{p}=.03)$. The study performed the Mann-Whitney $U$ test to find out which educational levels such difference derived from. At this stage, Bonferroni correction was used to reduce Type 1 errors, and the significance level was set at $.01(.05 / 4=.0125)$.

Table 5. Teacher efficacy level of participants based on independent variables

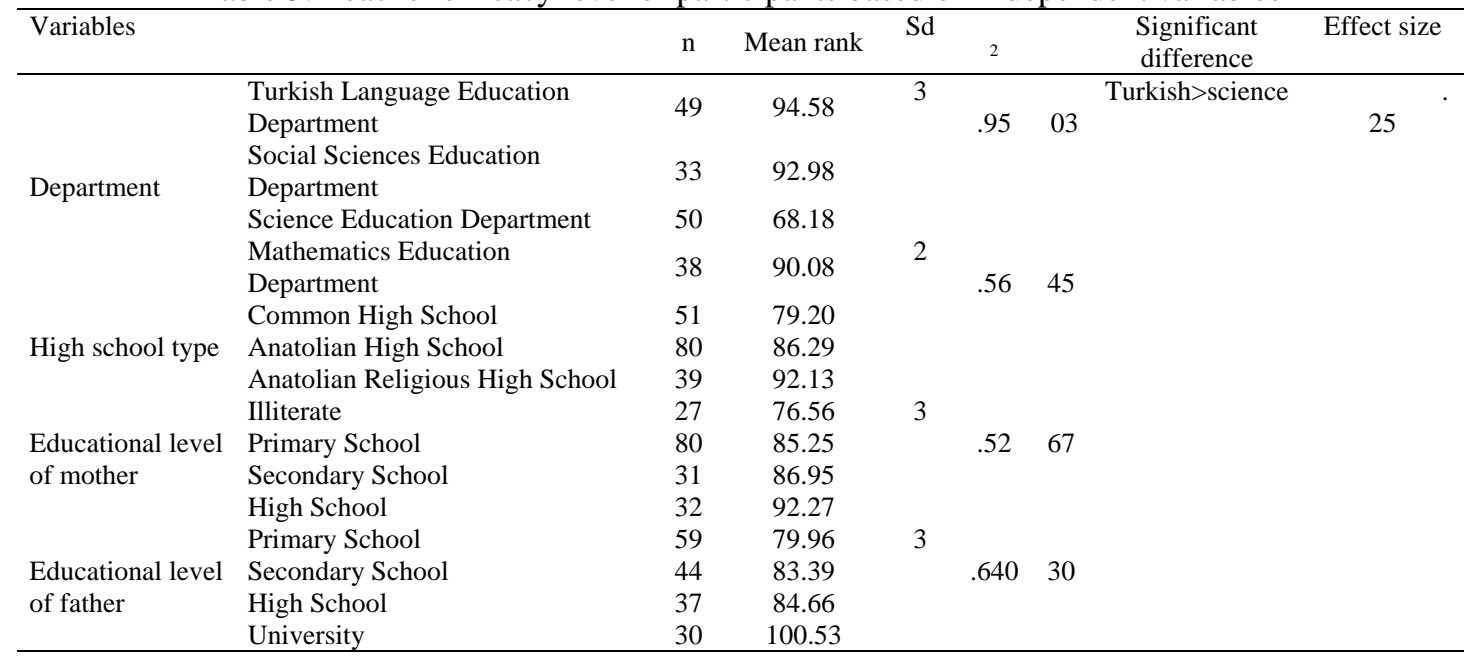


The results of the analyses indicated that prospective teachers in Turkish Education Department had higher teacher efficacy compared to their peers in Science Education Department ( $U=860 ; p=.011)$. Analysis of the effect size column in the table displays that the department variable had a small effect on teacher efficacy scores of the students [14]. According to Table 5, there was no significant difference between teacher efficacy scores of the participants based on high school type and educational level of parents ( $p>.05)$.

The Mann-Whitney $U$ test was performed to investigate whether teacher efficacy scores of the prospective teachers differed significantly in relation to gender. The findings are given in Table 6 . According to Table 6, there was no significant difference in teacher efficacy scores of the participants based on gender ( $p>.05)$. This finding can be interpreted as that occupational self-efficacy levels of the female and male participants were similar.

Table 6. Results of the mann-whitney u test based on gender

\begin{tabular}{cccccc}
\hline Gender & $\mathrm{n}$ & Mean rank & Rank sum & $\mathrm{U}$ & $\mathrm{p}$ \\
\hline Female & 94 & 80.61 & 7577.50 & 3112.50 & .15 \\
Male & 76 & 91.55 & 6957.50 & & \\
\hline
\end{tabular}

The analysis of Table 7 reveals that the participants' scores on the Teachers' Sense of Efficacy Scale differed significantly in relation to learning styles $\left(\mathrm{X}^{2}=10.28, \mathrm{p}<.05\right)$. According to the result of the MannWhitney U test, prospective teachers with "diverging" learning style had higher teacher efficacy scores than prospective teachers with "converging" learning style $(\mathrm{U}=434.50 ; \mathrm{p}=.018)$. In addition, teacher efficacy scores of the participants with "assimilating" learning style were higher than the scores of the participants with "converging" learning style.

Table 7. Relationship between occupational self-efficacy and learning style

\begin{tabular}{cccccccc}
\hline $\begin{array}{c}\text { Teachers' Sense of } \\
\text { Efficacy Scale }\end{array}$ & Learning style & $\mathrm{n}$ & Mean rank & $\mathrm{Sd}$ & $\mathrm{X}^{2}$ & $\mathrm{p}$ & Significant difference \\
\hline \multirow{3}{*}{ Total } & Accommodating & 35 & 81.23 & 3 & 10.28 & .01 & Diverging> Converging \\
& Diverging & 62 & 96.91 & & & & Assimilating > Converging \\
& Converging & 43 & 67.17 & & & & \\
\hline
\end{tabular}

Aimed at examining learning styles and teacher efficacy in prospective teachers, the study found that the majority of the participants predominantly had "diverging" learning style while few of them had "assimilating" learning style as preferred way of learning. This result demonstrates that the prospective teachers in the study group mostly adopt Concrete Experience and Reflective Observation, and hence, they learn better through sensing and observing. There are studies in the relevant literature reporting similar results with this subscale. For instance, [15] found the dominant learning style of 50 prospective teachers in Physics Department was "diverging", and it was followed by accommodating, converging and assimilating learning styles, respectively. In her study, [16] reported that "diverging" learning style was the dominant learning style preferred by prospective teachers in different departments in technical education faculty of a university. [17] Also found that 606 prospective teachers in the departments of Science, Mathematics and Primary School Teaching had "diverging" learning style as dominant learning strategy. In another study, Singh and Singh (2014) reported that the dominant learning style of 190 prospective teachers studying science, humanities and social sciences was "diverging". The analysis of the relationship between learning styles and occupation indicates that dominant learning style of the majority of teachers is "assimilating" [12]. This finding is also supported with relevant research [18-21]. The reason for finding "diverging" learning style as dominant learning style of most participants in the present study may be the impact of central exams they will take at the end of their training period, and the learning environment they experience. The fact that prospective teachers preparing for Public Personnel Selection Examination (KPSS) mostly study on their own, the recognition of the need for being more patient and careful in learning process, experiencing a difficult studying period due to knowing that they can become a teacher only after passing a three-stage exam, and the possibility that this process may cause prospective teachers adopt a more sensory approach may have an impact on the learning styles of the participants. Indeed, it is well-known that individuals with "diverging" learning style are inclined to become emotional, prefer individual studying when learning, and become patient and careful in learning process [22, 23].

The study found that the prospective teachers' learning styles differed significantly based on the department variable. It was found that dominant learning style among the majority of students in Turkish

The examination of learning styles and teacher efficacy in prospective teachers... (Tazegül Demir Atalay) 
Education Department was “diverging”. It was followed by assimilating, converging and accommodating learning styles, respectively. In other words, prospective teachers in Turkish Education Department predominantly had diverging and assimilating learning style, whereas converging and accommodating learning styles were least preferred. As for other departments; students in Social Sciences Education Department had converging and accommodating learning styles most, and assimilating and diverging learning styles least; students in Science Education Department preferred diverging and converging learning styles most, and accommodating and assimilating learning styles least; and participants in Mathematics Education Department predominantly had diverging and assimilating learning styles while they preferred converging and accommodating learning styles least. These results suggest that distribution of learning styles among the participants in Turkish and Mathematics Education departments, and those in Science and Social Sciences Education departments bear similarities. Considering that learning style is an indicator of individual differences, can change over time, and differs in relation to demographic characteristics of learners such as age, gender, cultural characteristics, academic achievement and preferences in the process of knowledge acquisition [24], the finding of the study concerning the difference in learning styles based on department may be accepted normal. Indeed, [25] indicated that learning style differed even between students attending daytime and evening classes in the same department. A study by [18] investigating prospective teachers' learning styles based on diverse variables found that students' learning styles differed in relation to their department. [26] Also reached the conclusion that learning styles differed among prospective teachers in relation to their respective disciplines.

Another finding of the present study was that the prospective teachers' learning styles did not differ significantly based on gender. This finding is also supported by several studies reporting that the dominant learning style of students did not differ based on gender [27-31]. However, there are also other studies indicating that dominant learning style of students vary based on the gender variable [9, 32-35]. In this regard, the difference between the study results may be caused by diversity of the study samples or the use of different measuring tools to identify learning styles.

The study results also demonstrated that the majority of prospective teachers who graduated from Common High School or Anatolian Religious High School mostly had "diverging" learning style while those who graduated from Anatolian High School preferred "converging" ( $n=25)$ and "diverging" $(n=24)$ learning styles. However, the results of statistical analyses revealed that the participants' learning style did not significantly differ in terms of the type of high school they graduated from. Similar results were also reported by $[19,21,27]$.

Furthermore, the study found that learning styles of the participants did not differ based on educational level of father, whereas there was a significant difference in learning styles based on educational level of mother. The dominant learning style for most of the students whose mothers were illiterate, primary school graduate or secondary school graduate was "diverging", and most of the participants who had high school graduate mothers had "converging" learning style. The analysis of effect size indicated that educational level of mother had a moderate effect on learning styles. In line with the finding on this subdimension of the study, [32] maintained that there was a significant difference between educational level of mother and learning style of students. [36] Reported that learning style of hearing impaired students varied in relation to educational level of mother. Moreover, [37] found a statistically significant difference between learning style of participating students and educational level of mother, whereas no statistically significant difference was observed with regard to educational level of father. In the literature, there are also studies indicating that learning style differed based on educational level of father $[36,38])$. The reason for such impact of educational level of mother and/or father on learning styles may be parental influence on occupational choices of students. [39] asserted that preferences of the family is a determining factor for students' university choice. [40] Stated that the will of the family was a significant factor for senior high school students in their choice of department.

The study also came to the conclusion that the prospective teachers had a high level of teacher efficacy. Actually, this finding is very promising. The fact that prospective teachers who were in the home stretch of their pre-service education had high self-efficacy beliefs that they can engage students in class actively or covertly, use instructional methods and techniques compatible with the aim and content of the course, organise learning environment according to the needs and interests of students, determine success level of students, accomplish class management, minimise unwanted behaviours in the classroom, etc. when performing the teaching profession may also be considered as an indication of higher professional motivation. As is stated by [2], perceived self-efficacy is an important factor that motivates individuals. If people do not believe they can achieve the desired outcome, they will not be motivated enough despite the existence of other drivers around them. Thus, self-efficacy is linked to motivation. The role of teachers and level of their professional motivation cannot be denied in achieving effective learning. Teachers with high occupational self-efficacy, and hence high professional motivation believe that students with learning 
difficulties can learn with sufficient endeavour, these teachers can cope with negative effects of environment on instruction process also with support of the family, are open to new ideas, willing to apply innovations in the classroom environment, have lower occupational burnout and are more supportive of student autonomy [41-43]. However, teachers with low occupational self-efficacy think there is nothing to do when students are not motivated enough to learn, and they cannot prevent the negative impact of environment and family [42]. In line with the finding of the present study, there are research findings in the relevant literature reporting that prospective teachers have high teacher efficacy [44-47].

The study indicated that teacher efficacy levels of the participants differed significantly based on department. Considering mean ranks on the Teachers' Sense of Efficacy Scale scores of the participants, it was concluded that prospective teachers studying social sciences usually saw themselves more sufficient in their profession compared to the participants studying science. According to the results of analyses, it was found that the department variable had a small effect on occupational self-efficacy, the significant difference between the departments resulted from the difference between participants in Turkish Education and Science Education departments, and participants in Turkish Education Department had higher occupational selfefficacy than those in Science Education Department. In their study, [48] observed that occupational selfefficacy levels of prospective teachers differed based on department, and prospective teachers in Turkish, Social Sciences, Music and Art Teaching programs had higher perceived self-efficacy than those in other programs. [49] Reported that there were significant differences between the scores of prospective teachers for two scale factors -efficacy in student engagement and efficacy in classroom management- on the Teachers' Sense of Efficacy Scale based on department, and students in Turkish Education Department saw themselves more sufficient regarding these factors compared to students in other departments. Furthermore, [50] found that prospective teachers in Mathematics Department had lower perceived self-efficacy with regard to student engagement and classroom management on the Teachers' Sense of Efficacy Scale than prospective teachers in other departments.

Lower teacher efficacy in prospective teachers in Mathematics and Science departments may be resulting from the negative attitude usually developed by students toward these disciplines beginning from primary school. [51] Asserted that this negative attitude is not specific to Turkey, and there is a common belief around the world that students have different concerns and fears regarding mathematics class in particular. Relevant studies indicated that students' developing concerns regarding these courses and their increase over time may be affected by authoritarian attitudes of teachers, students' failure in establishing links between content of the course and life due to frequent use of traditional instructional methods and techniques, lack of role models, the impact of gender and racial judgments, and influence of scientists in popular media [51-54]. Based on these findings, prospective teachers' lower occupational self-efficacy may result from being aware of the challenges they will face due to knowing that students usually have negative attitudes toward mathematics and science.

The results of the study indicated that teacher efficacy levels of the participants did not differ based on the type of high school they graduated from and educational level of parents. That it had been a while since they graduated from high school, and professional teaching knowledge is predominantly introduced in undergraduate level may have caused students to develop perceived self-efficacy according to the knowledge and skills they learned in these classes. Similar to the result of the present study, [55] reported that teacher efficacy in prospective teachers did not show a statistically significant difference in relation to the type of high school they graduated from. On the other hand, [56] found no significant difference in teacher efficacy among prospective teachers based on educational level of parents. In addition, the present study indicated that teacher efficacy did not differ significantly among prospective teachers based on gender. This result demonstrates that the level of occupational efficacy in female and male prospective teachers was similar. Factors such that teaching is an easily attainable profession under current circumstances in Turkey, the perception toward roles and responsibilities of women and men in society has started to be shaped in line with the principle of "equality", and no difference in learning environments based on gender, etc. may be the cause of similar occupational self-efficacy beliefs in female and male participants. In a similar vein, [55, 5760] maintained that gender factor did not have a significant impact on teacher efficacy in their studies.

Finally, the study found that teacher efficacy of the participants differed in relation to learning styles, and students who had "diverging" and "assimilating" learning style as dominant learning style had higher occupational self-efficacy than those with "converging" learning style. As teaching is a profession based on trial and practice, prospective teachers with converging and accommodating learning style, who learn through acting, may be expected to have higher teacher efficacy. [61] Reported that perceived selfefficacy level of prospective science teachers was significantly different in relation to learning styles, and prospective teachers with accommodating learning style had higher perceived self-efficacy than those who had converging and assimilating learning styles. However, as stated above, prospective teachers' being in the last phase of pre-service training, and being in a difficult learning process to prepare for Public Personnel

The examination of learning styles and teacher efficacy in prospective teachers... (Tazegül Demir Atalay) 
Selection Examination may have impact on their learning style, and hence occupational self-efficacy which is related to learning style. The findings on this subdimension of the study are also supported by [62] who maintained that there was a relationship between self-efficacy beliefs of prospective science teachers regarding science teaching based on learning styles, and students with "diverging" and "assimilating" learning styles had higher perceived self-efficacy than students with "converging" learning style.

\section{CONCLUSION}

As a result of the study, it was determined that the dominant learning style of the participant teacher candidates' was "diverging" and that the learning styles differed according to the departments they were studying. It was determined that the dominant learning style of the candidates studying in Turkish Education was "diverging" and in Social Studies Education was "converging". The candidates studying in Science and Mathematics Education as a majority, "diverging" have been identified as having learning styles. As a result of the analyzes performed, it was revealed that the department variable has a moderate effect on the learning styles of the learners. While the gender of the teacher candidates, the type of secondary education they graduated, and their father's education status did not differ significantly according to their learning styles, their mother education statuses were significantly different according to their learning styles. Mother education status variable which has a moderate effect on the learning styles of the participants showed a significant difference at the level of high school. It has seen that the dominant learning style of the candidates whose mother education status was "high school" was "converging".

In the study, it was determined that the Teacher Self-Efficacy Scale scores of the teacher candidates on the basis of the sub-factors and sum of the scale were "sufficient" level. This result indicates that the teacher candidates who constitute the study group have high levels of professional self-efficacy. As a result of the analyzes, it was determined that the candidates did not differ significantly according to their gender, the type of secondary education they graduated from, their parents' educational status, but the candidates differed significantly from the departments they studied. It was determined that the teacher self-efficacy levels of the teacher candidates who were studying in Turkish Education were higher than the teacher candidates studying in the Science Education. It is also among the research findings that the department variable has a low effect on the Teacher Self-Efficacy Scale scores of the learners. In the study, it was determined that the professional self-efficacy levels of the teacher candidates differed significantly according to their learning styles. it was found that the teachers' self-efficacy scores who had predominantly "diverging" learning style were significantly higher than the candidates who had "converging" and the teachers' selfefficacy scores who had "assimilating" learning style were significantly higher than the candidates who had "converging".

Further studies should be conducted to explore teacher efficacy in prospective teachers. The results of these studies should be evaluated as a needs analysis for pre-service teacher training, and necessary measures (giving more focus to courses on professional teaching knowledge in the curricula, increasing the credits of applied aspects of the courses, the distribution of courses on school experience and teaching practice to different educational levels, and self-assessment and peer review of prospective teachers by using instructional techniques like microteaching), if any. Further studies also should be conducted to explore variables that can predict teacher efficacy of prospective teachers, and the validity of the results of these studies should be increased.

\section{REFERENCES}

[1] S. Hidi and P. Boscolo, "Motivation and writing," Handbook of writing research, vol. 144(157), pp. 304-310, 2006.

[2] A. Bandura., Self-efficacy in vs ramachaudran (ed.) encyclopedia of human behavior, Ed: New York: Academic Press, 1994.

[3] F. H. B1kmaz., "The validity and reliability study of the classroom teachers' self-efficacy belief scale in science teaching," National Education Journal, vol. 161, 2004.

[4] İ. E. Gencel., "Learning styles, instruction based on kolb's experential learning theory, attitude and social studies achievement PhD," DE ̈U Institute of Educational Sciences, 2006.

[5] D. A. Kolb., Experience as the source of learning and development, Upper Sadle River: Prentice Hall, 1984.

[6] M. Peker., "Kolb learning style model," National Education Journal, vol. 157, pp. 185-192, 2003.

[7] Ö. Hasırcı Kaf., "Learnıng styles of prospectıve prımary school teachers: Çukurova unıversıty case," Journal of Theory and Practice in Education, vol. 2(1), pp. 15-25, 2006.

[8] M. Mutlu and M. Aydoğdu, "Long learnıng approach of kolb in science education," Pamukkale University Faculty of Education Journal, vol. 13(13), pp. 15-29, 2003.

[9] M. Dikmen, M. Tuncer, and M. Şimşek, "Relationship between learning styles and attitudes towards learning," International Social Rearch Journal, vol. 11(57), pp. 388-400, 2018. 
[10] M. Tschannen-Moran and A. W. Hoy, "Teacher efficacy: Capturing an elusive construct," Teaching and teacher education, vol. 17(7), pp. 783-805, 2001.

[11] Y. Çapa, J. Çakıroğlu, and H. Sarıkaya., "The development and validation of a Turkish version of teachers' sense of efficacy scale," Education and Science, vol. 10(117), pp. 74-81, 2005.

[12] P. A. Aşkar, B., "Kolb learning style inventory," Education and Science, vol. 87, pp. 37-47, 1993.

[13] C. Eker., "A research on classroom teachers' self-efficacy belief levels," Uşak University Social Sciences Journal, vol. 7(1), pp. 62-78, 2014.

[14] J. Pallant, SPSS user manual Step-by-step data analysis with SPSS. An1 Publishing, Ankara, 2016.

[15] Ş. Kandil-İngeç, "Turkish pre-service physics teachers' preferred learning styles," Educational Research and Reviews, vol. 10(4), pp. 403-415, 2015.

[16] G. Ekici., "According to Gregorc and Kolb learning style models, examining the learning styles of teacher candidates in terms of gender and general academic achievement," Education and Science, vol. 38(167), pp. 211225, 2013.

[17] B. Cavas., "A study on pre-service science, class and mathematics teachers' learning styles in Turkey," Science Education International, vol. 21(1), pp. 47-61, 2010.

[18] F. Çelik, R. Yalçın, Ö. Gök-Çatal, and A. Aydın., "Examining the learning styles of teacher candidates in terms of some variables," Mehmet Akif Ersoy University Faculty of Education Journal, vol. 32, pp. 114-129, 2014.

[19] G. Çiğdem and A. Memiş, "Investigation of learning styles of classroom teacher candidates and their attitudes towards the teaching profession in terms of various variables," Çukurova University Faculty of Education Journal, vol. 3(40), pp. 57-77, 2011.

[20] T. G. Dikmen and A. S. Saracaloğlu, "Investigation of learning styles of teacher candidates in terms of various variables," Adnan Menderes Univesity Faculty of Education Educational Science Journal, vol. 2(1), pp. 52-64, 2011.

[21] E. Karademir and Ö. Tezel, "Examining the learning styles of primary school teacher candidates in terms of demographic variables," Pamukkale University Faculty of Education Journal, vol. 2(28), pp. 129-145, 2010.

[22] S. Kurbanoğlu and B. Akkoyunlu, "Learning styles of information management students," Turkish Librarianship, vol. 22(3), pp. 296-307, 2008.

[23] N. Özdemir, A. Kesten, and P. Işkın., "The effect of teacher training on the learning styles of prospective teachers of social studies," Universal Journal of Educational Research, vol. 5(3), pp. 396-407, 2017.

[24] B. C. a. R. C. Directorate. (2018, 15.01.2019). Learning styles and study habits teacher's handbook, [Available] http://bilecikram.meb.k12.tr/meb_iys_dosyalar/11/01/130586/dosyalar/2018_10/25140818_YYrenme_Stilleri_ve_ YalYYma_AlYYkanlYklarY_YYretmen.pdf

[25] F. Topuz and O. Karamustafaoğlu, "Investigation of learning styles in terms of various variables: Science teacher candidates," Dicle University Ziya Gökalp Faculty of Education Journal, vol. 21, pp. 30-46, 2013.

[26] E. Tezci and N. Ataseven, "Effects of learning style and demographic factors on learning strategies," Journal of Educational Sciences Research, vol. 6(1), pp. 211-225, 2016.

[27] S. Açışl1., "Investigation of teacher candidates' learning styles and critical thinking dispositions," Necatibey Educational Faculty Electronics Science and Mathematics Education Journal (EFMED), vol. 9(1), pp. 23-48, 2015.

[28] Ş. Beşoluk and İ. Önder, "Investigation of teacher candidates' learning approaches, learning styles and critical thinking tendencies," Primary Education Online, vol. 9(2), pp. 679-693, 2010.

[29] Ş. Can, "Investigation of the relationship between learning styles of classroom teacher candidates and some variables," Hacettepe University Faculty of Education Journal, vol. 41, pp. 70-872, 2011.

[30] F. Çelik and H. Şahin, "Examination of learning styles physical education and sports teaching teacher candidates in terms of gender and education level (MAKÜ Sample)," Buca Faculty of Education Journal, vol. 31, pp. 23-38, 2011.

[31] A. Kaya, H. Bozaslan, and S. F. Durdukoca., "Examining the relationship between the learning styles and the study habits of teacher candidates," Electronic Journal of Social Sciences, vol. 11(41), pp. 131-146, 2012.

[32] S. Bakır and H. Mete, "Learning styles of secondary school students: Burdur city sample," Ahi Evran University Kirşehir Faculty of Education Journal (KEFAD), vol. 15(3), pp. 127-145, 2014.

[33] K. F. Fadlelmula., "Pre-service teachers' learning styles and attitudes toward teaching profession," Turkish Journal of Teacher Education, vol. 4(1), pp. 18-27, 2015.

[34] S. E. Severiens and G. T. M. T. Dam, "Gender differences in learning styles-a narrative review and quantitative metaanalysis," Higher Education, vol. 2, pp. 487-501, 1994.

[35] E. A. Wehrwein, H. L. Lujan, and S. E. DiCarlo, "Gender differences in learning style preferences among undergraduate physiology students," Advances in Physiology Education, vol. 31, pp. 153-167, 2007.

[36] C. Aslan., "An investigation on learning styles of students who have hearing deficiencies," Turkish Journal of Education, vol. 2(2), pp. 4-15, 2015.

[37] Ö. Şen., "Learning styles of secondary school 8th grade students," Mersin University Faculty of Education Journal, vol. 14(2), pp. 852-862, 2018.

[38] T. Demir and Ü. Şen, "A research on learning styles of visually impaired students in terms of various variables," International Social Rearch Journal, vol. 2(8), pp. 154-161, 2009.

[39] M. Koçyiğit and E. Eğmir, "Higher education, why and how: A view from the perspectives of university students," Route Educational and Social Science Journal, vol. 2(4), pp. 241-256, 2015.

[40] M. Koçyiğit, E. Eğmir, and M. Akçil, "A look at education and higher education through the eyes of high school students," MANAS Social Researches Journal, vol. 7(3), pp. 119-140, 2018.

\footnotetext{
The examination of learning styles and teacher efficacy in prospective teachers... (Tazegül Demir Atalay)
} 
[41] A. Brouwers and W. Tomic, "A test of the factorial validity of the Teacher Efficacy Scale," Research in Education, vol. 69, pp. 67-79, 2003.

[42] S. Gibson and M. H. Dembo, "Teacher efficacy: A construct validation," Journal of Educational Psychology, vol. 76(4), pp. 569-582, 1984.

[43] J. Ross and C. Bruce, "Professional development effects on teacher efficacy: Results of randomised field trial," The Journal of Educational Research, vol. 101(1), pp. 50-60, 2007.

[44] N. Ekinci, "Teacher self-efficacy beliefs of candidate teachers in education faculty and pedagogical formation program," Educational Process: International Journal, vol. 1(1-2), pp. 19-26, 2012.

[45] P. Gavora, "Slovak pre-service teacher self-efficacy: Theoretical and research considerations," The New Educational Review, vol. 21(2), pp. 17-30, 2010.

[46] D. Pendergrast, S. Garvis, and J. Keogh, "Pre-service student-teacher self-efficacy beliefs: An insight into the making of teachers," Australian Journal of Teacher Education, vol. 36(12), pp. 46-57, 2011.

[47] Ş. Ç. Taşkın and G. Hacıömeroğlu, "Adaptation of teacher self-efficacy belief scale to Turkish and self-efficacy beliefs of classroom teacher candidates," Dokuz Eylül University Buca Faculty of Education Journal, vol. 27, pp. 63-75, 2010.

[48] H. Demirtaş, M. Cömert, and N. Özer, "Self-efficacy beliefs of teacher candidates and their attitudes towards the teaching profession," Education and Science, vol. 36(156), pp. 96-111, 2011.

[49] R. Ö. Aydın and Y. E; Argon, T., "Perceptions of pre-service teachers on self-efficacy and postponing their desires in the academic field," Educational Sciences Journal, vol. 40, pp. 1-12, 2014.

[50] E. Yeşilyurt., "Teacher self-efficacy perceptions of teacher candidates," Electronic Social Sciences Journal, vol. 12(45), pp. 88-104, 2013.

[51] Ş. Aydin, 8th grade secondary school students' views on mathematics lesson and problem concept, Ph.D., Institute of Educational Sciences, Gazi University, Ankara, Unpublished, 2016.

[52] S. A. Jegede., "Students' anxiety towards the learning of chemistry in some nigerian secondary schools," Educational Research and Review, vol. 2(7), pp. 193-197, 2007.

[53] M. K. Udo, G. P. Ramsey, and J. V. Mallow., "Science anxiety and gender in students taking general education science courses," Journal of Science Education and Technology, vol. 13(4), pp. 435-446, 2004.

[54] Ş. Uluçınar-Sağır., "Science anxiety scale for elementary students," Buca Faculty of Education Journal, vol. 37, pp. 1-20, 2014.

[55] G. Ekici., "The effect of classroom management course on teacher self-efficacy perception of teacher candidates," Hacettepe University Faculty of Education Journal, vol. 35, pp. 98-110, 2008.

[56] A. Derman., Self-efficacy perceptions of chemistry teacher candidates and attitudes towards teaching profession. Thesis, PhD, Institute of Science, Selçuk University, Konya, Unpublished 2007.

[57] G. H. Berkant., "An examination of teacher self-efficacy perceptions of teacher candidates," Journal of Educational Reflections, vol. 1(2), pp. 1-17, 2017.

[58] S. T. W. Moalosi and N. Forcheh, "Self-efficacy levels and gender differentials among teacher trainees in colleges of education in Botswana," Journal of Education and Learning, vol. 4(3), pp. 1-13, 2015.

[59] B. B. Telef, "Investigation of teachers' self-efficacies, job satisfactions, life satisfactions and burnouts," Primary Education Online, vol. 10(1), pp. 91-107, 2011.

[60] M. Üstüner, H. Demirtaş, M. Cömert, and N. Özer, "Self-efficacy perceptions of Secondary school teachers," Mehmet Akif Ersoy University Faculty of Education Journal, vol. 9(17), pp. 1-16, 2009.

[61] A. Köse., The relationship between learning styles of science teacher candidates, their teaching strategies and science teaching self-efficacy beliefs (ÇOMÜ sample). Thesis, MA, Institute of Social Sciences, Çanakkale Onsekiz Mart University, Çanakkale, Unpublished 2010.

[62] P. Denizoğlu., The evaluation of the relationship between science teacher candidates' attitudes towards science teaching self-efficacy beliefs, learning styles and science teaching, Master, Institute of Social Sciences, Çukurova University, Adana, Unpublished, 2008. 